\title{
Political Imbroglios and Social Radicalization in the Novels of Fatima Bhutto: A Case Study
}

\author{
Sidra Anam ${ }^{1}$, Muhammad Arfan Lodhi ${ }^{2, *}$, Rehana Anwer ${ }^{1}$ \\ ${ }^{1}$ The Department of English, NCBA \& E University, Lahore, Punjab, Pakistan. \\ ${ }^{2}$ Higher Education Department, Collegiate Wing, Lahore, Punjab, Pakistan.
}

How to cite this paper: Sidra Anam, Muhammad Arfan Lodhi, Rehana Anwer. (2021). Political Imbroglios and Social Radicalization in the Novels of Fatima Bhutto: A Case Study. The Educational Review, USA, 5(8), 257-269.

DOI: $10.26855 / \mathrm{er} .2021 .08 .002$

Received: June 28, 2021

Accepted: July 25, 2021

Published: August 19, 2021

Corresponding author: Muhammad Arfan Lodhi, Higher Education Department, Collegiate Wing, Lahore, Punjab, Pakistan.

Email: samaritan_as@hotmail.com

\begin{abstract}
The aim of this research is to examine the novels of Pakistani writer Fatima Bhutto. Novels 'The Shadow of the Crescent Moon' (2013) and 'The Runaways' (2018) capture the concept of political imbroglios, traumas of war which the people of Tribal areas are still confronting and social radicalization respectively. The intention of this examination is to emphasize the working of politics, political imbroglios at social, political and personal level in the Tribal area; post 9/11 scenario in Mir Ali. The author captures our attention towards the understanding and reality of 'war on terror' and towards those who are facing its consequences - the worst victims-by drawing the political and social relationships and here lay the prejudicial and evil conflict flourish. Such type of fiction regarding 'war on terror' reveals the variety of ideological constructions concerning the problems. It also depicts the psychological and emotional disorders of the indigenous people suffering after 9/11 catastrophe. Bhutto in 'The Runaways' reveals the lives of three radical characters who in search of their identity and place in this world join the terrorist organizations. The incidents of 9/11 prompted considerable changes in global relations. It has influenced socio-political, external security and internal security both and monetary situations in Pakistan. The disputable issues like US drone strikes in Pakistan's tribal regions have prompted violence, extremism and terrorist attacks. Hence, the events of 9/11 brought an endless loop of destruction and terrorism in Pakistan with various impacts on the public and state.
\end{abstract}

\section{Keywords}

Political imbroglios, 9/11, Radicalization, terrorism, War on Terror, trauma, lost identity

\section{Introduction}

The niece of previous Leader of Pakistan Benazir Bhutto, the granddaughter of previous PM of Pakistan Zulfiqar Ali Bhutto and Murtaza Bhutto's daughter Fatima Bhutto is a Pakistani writer brought into the world on 29th May in Kabul into a political dynasty. Her most notable work includes 'The Shadow of the Crescent Moon', 'The Runaways', 'The Democracy' and a memoir 'Songs of Blood and Sword'. She writes from the heart and her experience with the complex political and social issues of the region really shines through. Sethna (2014) opines that Bhutto is a proficient writer in writing political fiction as she generates an extraordinary story of war, betrayal, political unrest and lost identity with literary skills. 'The Shadow of the Crescent Moon' is very first novel written by Fatima Bhutto. It is an interesting novel fix in the tribal region of northwest Pakistan, a complicated place with complicated politics all of which Bhutto comes 
to grip with lyrical embellish. Fatima Bhutto aptly describes the fundamental issues existing in Pakistani society. She narrates the story in such a way that it covers each and every problem ranging from social and domestic issues, economic deprivation and political complexities. She has vividly thrown light on these issues to explore some of the solutions and answers to the questions. In novel 'The Shadow of the Crescent Moon' (2013) and 'The Runaways' (2018) Bhutto has skillfully tackled the political complexities and social problems at personal and social level. It is about radicalization and the experiences and anxieties of the young people that bring them to the crisis. Bhutto has drawn the subtleties of problematic human adversity, regarding war and its aftermaths.

\subsection{Background of the Study}

According to Suganami (2003), the occasions of September 2001 can unquestionably be regarded the most tumultuous event of 21st century. It caused extreme social and political changes in the world. It has destroyed the huge building in New York and killed many people. Lepeshkov (2010) views terrorism refers to the most dangerous threat to the interests of people and the State. This particular research focuses on political complexities, social radicalization and convolutions in the novels. Published in 2013, 'The Shadow of the Crescent Moon' fixes in Pakistani tribal belt of Waziristan in a particular region known as Mir Ali nearby the Afghan border is the tale of three blood brothers and two youthful women confined by native Pakhtun rituals. It is an investigation of 'war on terror' experienced by a younger generations in Pakistan. As the novel opens before the Eid holidays, the 3 brothers Aman Erum, Hayat and Sikandar choose to make a tour of different mosque as it is hazardous and insecure to put all the members of family jointly at the same time in one mosque. Bhutto shows the strange sense of dejection in their lives that nourishes until the end. Thakur (2012) states that the drone attacks by America have killed many people in Pakistan's tribal region. The 'war on terror' has disastrous effects and it provoked hate sentiments towards America. Moreover, it has destroyed the social, political and economic status of the country. 'The Shadow of the Crescent Moon' is about the three stories, three sufferings in which Bhutto has tried to echo the unheard voices and untold realities. Her first novel 'The Shadow of the Crescent Moon' narrates the unending war, Taliban killed by American drones, Shiia Muslims bombed by Sunni Muslims and covert generations fighting for liberty from primary government. Aman Erum, the eldest spends years in American to study and make something for his bright future has returned to Mir Ali located near the Afghan border placed in Pakistan's Waziristan tribal belt, he left behind his young brothers and beloved Samarra, return to the mosque that morning. The writer stresses upon the vision to go forward your future you have to defeat past. In this novel the changing ideologies such as allegiances, liberalism and betrayal are working. Many years before a younger and nervous Aman Erum travelled to Islamabad for applying for visa in American embassy. Before this interview he had never worn a suit and when the interviewer asked about 9/11 the answer was; two airplanes target and hit the international buildings, this was heard by the people of Mir Ali. Years later he realized that he spent a big amount to get American visa for himself.

Aman Erum and Samarra were deeply committed to the independence movement he realized that he and his dreams would never fit into the provincial life he saw around him. Sikandar's middle brother is a doctor, he wanted to go abroad but he chooses to work in a town's underfunded hospital where the medicine, vaccines and antibiotic are expired. A psychologist Mina and Sikandar her husband working in the same hospital had a son Zalan who was murdered in the hospital by attack. They used to attend the funerals of children as a way to find their son. At one of the funerals she speaks about Taliban's attack on hospital, and death of her son. There is visible personal catharsis but there is no resolution. Hayat is the youngest brother an idealistic has involved with Samara, fighting for independence and they are part of the Mir Ali insurgent movement.

Radicalization is a complex cycle where an individual or a group accepts an extreme philosophy or conviction that acknowledges uses or disregard violence to gain a particular political or social status. In this process people support violent extremism to join terrorist organizations. Fatima Bhutto's second novel 'The Runaways' deals with radicalization and identity crisis observed through the eyes of its sensitive characters. Anita Rose, Monty and Sunny are the title characters of the novel. In this novel, she describes how the alienation, disgruntle and poverty become the route way towards Islamist extremism.

The purpose of this study is to discuss the reviews and the opinions of the critics on the issues that have been raised in Bhutto's 'The Shadow of the Crescent Moon'. Meanwhile, this study deals with the fact that although there have been raised so many perspectives and issues in Bhutto's novels the political imbroglios and social radicalization perspectives are still a direction that has not been dealt with in detail rather there is still much to say and assert on these issues. This literature review provides a reasonable discussion of the objective of the present study. Written responses towards 'War on Terror' by Jadoon, Wasif and Imtiaz (2018) are of the view that novel 'The Shadow of the Crescent Moon' fights against the formulated thoughts about the 'war on terror'. The author captures our attention towards the reality of 'war on terror' and also toward the ones facings its consequences the worst affected by drawing political and social relation- 
ships and here lay the prejudicial and evil conflict flourish. According to Artemov and Kleimenov (2010), terrorism is a type of radical movement, primarily acknowledged in the political circle and showed in demonstrations of brutality. It creates the environment of anxiety in society.

Ohrnberger, Fichera and Sutton (2017) are of the view that those who take healthy food remain emotionally and psychologically positive, an individual's intellectual health has significant effects on his bodily well-being. Mujcic and Oswal (2019) assert that healthy and happy state is certainly correlated with consumption of fruit. The people of Mir Ali are not having the things that are needed for good and healthy life, and the refusal to satisfy a desire attacked physically and emotionally. They are helpless and desperate to realize the importance of their own life, the worth of the life of Mir Ali's population has minimized. War is the reason for injustice, desperation, and deprivation of proper health facilities for the citizens of Mir Ali residing there for years without any right of safety, security and significance for their existence. Every day thousands are killed brutally and treated inhumanly.

Abulof (2017) reasons that theory of need hierarchy by Maslow elaborates human instinct as something which majority of humans apprehend and acknowledge in others and in themselves as well. The use of expired, useless medicines and unrefrigerated polio vaccines are the pleasure and comfort for residents of Mir Ali they all cannot manage to get. It is a shocking and heartrending description of Earth's small-town Mir Ali where it is very difficult or annoying to get the vaccination for a healthy life and existence of infants, in this age of medical advancement where the man has found out curative treatment for deadly diseases like AIDS, HIV, cancer and Tuberculosis.

Radicalization is defined as a belief system that involves particular people and groups to adopt radical views to achieve social, religious, ideological and political objectives. It further promotes violent activities to achieve the agendas. Bhutto's novel 'The Runaways' clearly demonstrates the radical activities of the characters. They engage in terrorists activities to find their identity and place in this world.

\subsection{Statement of the problem}

The following study tends to highlight the political imbroglios and social radicalization in Fatima Bhutto's novels 'The Shadow of the Crescent Moon' and 'The Runaways'. Though much work has already been carried out on political imbroglios but this study discusses how the people of tribal region Mir Ali, suffer the aftermaths of 9/11 events. Moreover, the interpretation of the following study attempts to assess the political imbroglios, social radicalization, social issues, political extents and the high and low of the political winds.

\subsection{Research Questions}

1) What kind of political dilemmas and complexities did Fatima Bhutto discuss in her novel 'The Shadow of the Crescent Moon' and 'The Runaways'?

2) How has the violence been discussed in the novel 'The Shadow of the Crescent Moon' and 'The Runaways'?

3) How does political divisiveness take on human relationships?

4) How social radicalization is discussed in Bhutto's novels 'The Shadow of the Crescent Moon' and 'The Runaways'?

\section{Review of the related Literature}

\subsection{Literature and Politics}

Literature is the instruction of life and it provides a gateway to understand the simplicity or complexity of life through various lenses. Literature is the expedition towards the literary world. It gives attention on many topics associated to human life and it makes people capable to view the world with a pair of fresh eyes. Literature is of incredible importance and is concentrated upon as it gives the ability to join human relationships, and characterize what is correct and what is wrong. It is recognized to not exclusively be reflective of life, yet it can be used as a guide for the reader to notice and practice trustworthiness from. Politics is the set of activities. The individuals living in groups settle on choices between people, groups and nations. It is tied in with settling on arrangements between individuals so they can live respectively in groups like tribes, cities and nations. There are additionally conflicts between various nations. Efforts to tackle the issue with meetings are called strategy. If the issues are not settled by conciliatory gatherings they can prompt conflict or terrorism.

Literature displays or as such is the reflection of the general public. It assumes an uncommonly significant part. It reflects human action in society. It assists with uncovering social issues. The majority of the works in writing describes the social and political issues which assists individuals with understanding reality. It has a special capacity in forming and showing society in detail. It conveys the genuine occasions in the general public and presents it as a reflection of 
the society.

Literature is necessary to politics. Politics have been a productive source for literature since earliest times. In a political novel, politics performs a leading role. Modebadze (2010) argues with the issues of the description of politics. According to Heywood (1997) politics is described in such various ways: as it is the practice of authority, exercise of power, the generating collective decisions, the division of limited resources, the policy and use of deception or dishonest methods, manipulation, and economic consumption and likewise.

Miller (1962) argues that people encounter a great trouble when we try to explain the term politics. There is not mere one authorized accepted definition of politics but a large-scale range of definitions; specifically, the term politics has a great number of allowable, legitimate and reliable meanings. So, politics is a "weighted" term. Even reputable authorities and a person with a high level of knowledge in this field cannot accept what the subject is about. In other words, politics doesn't have a consistent specialized terminology, exact and satisfactory meaning with expressions of acknowledged importance. Be that as it may, if political investigator discusses traditionalism, communism, progressivism, politics, in this manner all of his audience puts on those his very own understanding, they have discrete and different conclusions and perspectives, however, and it is extremely hard to accomplish harmony between them.

People are extrovert and they are representative of society. In order to sustain one they have to unite and work together with efforts. When the persons work together with cooperation there is a requirement to make agreements about how the troubles that arise by working should be deduced. However, politics is the study of how such decisions are made. It may also be the study of how such decisions should be made.

Leftwich (1984) argues that politics subsists at every level, circumstances and in every domain of human societies. Politics is the determining characteristic of all social and cultural groups. Politics exists not only within the particular system of the state, but also takes place in private territory of life. Consequently, all people are in some manner involved in politics. It impacts the lives of all of us whether or not we take part in politics. Politics is at the heart of all collective and combined social activity, public and private, formal and informal in all multiple human groups, organizations and societies. Politics is a strategy wherein a few gatherings of individuals use their force and effect on work in a coordinated manner for some benefit. It is likewise considered as one of the greatest social issues as the most extreme number of decisions pronounced by the governments may not basically help the destitute individuals in the general public. Indeed, the leaders delight their egotistical advantages with the exploitation of public assets.

\subsection{Literature upon 'War on Terror'}

Jackson (2005) is of the view that the terminology of 'war on terror' has been intentionally formulated to introduce it as the just sensible, capable and innately 'great' reaction to terrorism. Fatima Bhutto's honorable work 'The Shadow of the Crescent Moon' (2013) uncovers the struggle against the formulated suppositions about 'war on terror'. The author enamors and hold our consideration with respect to the intensive agreement and truth of 'war on terror' and to the individuals who are enduring its unpleasant outcomes the most exceedingly worst victims by drawing the political and social relationships and here lay the biased and evil conflict flourish.

According to Bhutto, the in-depth perception of the 'War on Terror' expose the consequences that the young generation of Tribal Areas face and who are its worst victim neither Pakistani state nor the West have suffered its consequences. Such type of fiction on 'War on Terror' reveal the variety of ideological constructions concerning the problems, it also depicts the psychological and emotional disorders of the indigenous people suffering after 9/11 catastrophe.

Terrorism is an exhibition, which plans to make fear among basic people by unlawful strategies. It is a risk to humanity. It fuses individual or groups spreading brutality, riots, burglaries, attacks, kidnappings, doing combating, bombings, etc. It is an exhibit of shortcoming. It has no link with religion and Muslim or Hindu. Khan (2012) is of the view that the terrorist violent assaults on the World Trade Center affected the whole world. They attacked on 9 Sep 2001. The occasion changed the territory towards a region of a global political force. Shaikh (2009) dissects the beginning of Pakistan's issues and recognizes the identity crisis as the base of the multitude of ills confronting Pakistan. She distinguishes that Pakistan is battling continually to produce an agreement about Islam. She highlights the Pakistan's political and national identity.

\subsection{Literature and Radicalization}

Dolnik (2009) states intellectuals, scholars and numerous authors think about radicalization, extremism, militant radicalism and violence as replaceable wordings. There is no agreement on the portrayals of radicalism, terrorism and extremism which built it complex and difficult to comprehend. The 'fire fighter approach' to deal with evaluating the topic and western bias is making hindrances in researching why individuals arise as radicals and terrorists. According to 
Rais (2009), the researchers and learned people make a serious attempt to deal radicalization as not quite the same as terrorism and extremism. Religious extremists do not label themselves as religious radicals. However, revolutionaries name themselves as extremists. It infers that the word radicalization isn't constantly scowled on communism or socialism was viewed as extremist philosophies because it doubted the authenticity of existing establishments.

Naqi (2008) argues that radicalization would create extremism in the statement of the honesty and conclusiveness of one's convictions and their incomparability. Radicalization implies an extraordinary change acknowledged 'enthusiastically' about a specific problem. Extremism is the acknowledgment or selection of an unreasonable situation about any problem. However, terrorism implies coercively burden of thoughts, plans or perspectives, and so forth, on the reluctant. Radicalization cannot be an adequate reason for brutal assailant extremism and religious viciousness in light of the fact that most radicals are not associated with the executing of honest human beings on the grounds of religious contrasts. Roy (1994) states meanings of modernization and religious extremism continue to change. An association or a person can be named as religious radical.

Ramarkrishna (2010) states that the dangerous period of radicalization, which experts interprets as psychological radicalization and what divides the universe into two extreme degrees of good and evil. This 'extraordinary us' and 'detestable them' condition makes the path for embracing radical faith strategy that legitimize brutality for religio-political objectives and at last prompts terrorism. Ramkrishna observes that a few experts have the assessment that the 'virtual radicalism', is present in the society of Pakistan. Sial and Anjum (2010) are of the view that religious sensitivities run somewhere down in Pakistan and individuals regularly have a vicious or forceful disposition on issues addressing their religious convictions and global politics. Religion stays a center component of individuals' conviction framework and lack of education and basic reasoning confounds the perspectives on the vast majority of individuals on issue like extremism, radicalization, Jihad and terrorism.

\subsection{Theories of Radicalization}

There are numerous theories which define the idea of radicalization and its social and practical examples. A few theories are talked about are as under.

(1) Identity Theory

Erikson (1959) states that according to this theory the youthful people who have the less regard in the society have the fascination in take an interest in the political viciousness and are hoping to 'unite their personalities' and get confidence. The supposition of this hypothesis is significant with respect to Pakistan. Exactly, the authority of most of the assailant extremist parties was from the outset destitute families. They desire and request that they have a prominent place in the public. It would be unimaginable for the country to give a desirable place. They involve in radical activities for the assurance of their personality, confidence, and respect.

\section{(2) The Conveyor Belt Theory of Radicalization}

As indicated by this theory an individual who involve in a conflict made by aggressors' demonstrations to achieve political targets and aims. The individual can be inspired by specific convictions, creeds, speculations or thoughts under the notion that these feelings, doctrines, sentiments or hypotheses are right and genuine contrasted in relation to their partners. These radicalized portions of society execute honest regular citizens with guns. This theory is referenced on account of Muslim radicalization.

(3) Terror Management Theory

As per this theory every individual has a craving of living and has a terror of death. To keep away from death they involve in a group that is not defenseless. This gathering gives them safety. They think they are not feeble.

\section{Research Methodology}

According to Burns and Grove (1997) in qualitative research, there are number of important research design instruments that are commonly difficult and it provide accurate information of the research. Research methodology means the adoption of a plan in a systematic way in order to achieve the research objectives, findings and conclusion of the study. It is a master plan that is selected to include the different objectives of the study in a well-organized and insightful manner, so that the research issue is soundly being solved. It is like glue that connects all of the research elements. Leedy and Ormrod (2001) elaborated that research methodology is a way to collect, analyze and interpret data in order to have an insight towards a phenomenon. Research design is considered a necessary ingredient of the study for conducting any research study. It is not possible to conduct any study without the selection of an appropriate research de- 
sign. It works like the blue print of the study and it provides rich and quality information to identify the main issue. Case study research design is used as both a method and a methodology in research. Mills (2014) recognizes methods as techniques and procedures utilized in the specific study, while methodology is considered the lens through which the researcher analyze the perspectives and makes choices about the particular study. On the basic of research problem, the researcher adopted case-study research design for this study, because it is exploratory in nature. In the following research as it based on qualitative research the text was analyzed through codification. According to Saldana (2015) coding addresses the coarse craftsmanship that empowers skillful and imaginative translation and examination of the data. Fundamentally, the coding cycle makes a stock of your information. It is the basic activity of recognizing sections of significance in your information and marking them with a code. Coding is a process of indexing and categorizing the text in order to form a framework of thematic ideas about it. Moreover, research design guides the researcher to adopt necessary steps and follow appropriate strategies to achieve the research objectives. The present research was exploratory in nature and due to this reason its tools were criticism, research journals, research articles, newspaper, periodicals interview of the writer which were the source of data also. However, previous criticism, different articles, newspapers and journals were the ways of data collection towards appropriate solution of the study.

Table 1. Population Framework

\begin{tabular}{clcc}
\hline Name of the book & Author & Year of publication & Publisher \\
\hline $\begin{array}{c}\text { Whispers of the Desert Karachi } \\
\text { 8.50 a.m. 8 October 2005 }\end{array}$ & Fatima Bhutto & 1998 & Oxford University Press \\
Songs of Blood and Sword & Fatima Bhutto & 2006 & Oxford University Press \\
The Shadow of the Crescent Moon & Fatima Bhutto & 2010 & Nation Books \\
Democracy & Fatima Bhutto & 2013 & Penguin Viking \\
The Runaways & Fatima Bhutto & 2015 & Penguin Viking \\
\hline Fatima Bhutto & Table 2. Sample of the Study & Year of publication \\
\hline Nhe of the book & Author & 2013 & Publisher \\
\hline The Runaways & Fatima Bhutto & Patima Bhutto & Penguin Viking \\
\hline
\end{tabular}

According to Ary (1996), sample is characterized as a subset of the research population chooses to take an interest in an investigation, addressing the research population. For conducting a qualitative research study, different sampling techniques were used. This study is qualitative in nature than researchers used qualitative research technique to conduct this study. The population framework was the novels written by Bhuttoo within the period of 1998 and 2018 (see Table 1). The sample of the study was two novels, i.e., 'The Shadow of the Crescent Moon' and 'The Runaways' by Fatima Bhutto (see Table 2). Mixed purposeful sampling techniques were used to select the textual lines of both novels for the purpose of analysis.

\subsection{Framework of Analysis}

A well planned content analysis technique was used to organize and examine the data. Content or document analysis technique was used to establish the aura of positive words, subjects, thoughts or ideas inside some given subjective information. By utilizing content examination, researcher can measure and dissect the presence, implications and relationship of such certain words, topics or ideas. This technique was used to discuss and analyze the text through political perspectives. The findings were drawn on the basis of the careful examination of the compiled data. The framework of analysis taken for the present study was established from various perspectives.

Framework of analysis reveals that content investigation of the text was gone through at various levels. The components of political imbroglios and social radicalization were shown in this investigation (see Table 3). The sub-categories of political imbroglios, i.e., social confusion, communal confusion, national confusion, military confusion, and religious confusion and the sub-categories of social radicalization were traced out and discussed logically by highlighting political complexities. 
Table 3. Framework of Analysis

\begin{tabular}{lc}
\hline Category & Sub-categories \\
\hline Political Imbroglio & Social confusion \\
& Communal confusion \\
& National confusion \\
& Military confusion \\
Social Radicalization & Religious confusion \\
& Identity crisis \\
& Isolation \\
& Terrorist activism \\
\hline
\end{tabular}

\section{Analysis and Discussions}

Bhutto's 'The Shadow of the Crescent Moon' is a fictional case study. The personages of the narrative have been the sufferer of state hegemonic disappointment and discomfort accompanied by struggle, war, race-related and tribal conflict. Fatima Bhutto's remarkable debut novel records the existence of five youthful humans struggling to survive in a world on fire. The people of the Mir Ali are fighting for freedom. They had hopes that one day they will be free and ready to carry on with their life as indicated by their own will. Freedom is a way of thinking and expressing. It alludes to a condition of autonomy where you can do what you like with no limitation by anybody. It can be known as a perspective where you have the privilege and opportunity for work.

"With each battle for Mir Ali they held hope aloft and waited for the moment they would be free".

(Bhutto, 2013, p. 193).

Set about as the same time of the American invasion of Afghanistan, Bhutto's novel 'The Shadow of the Crescent Moon' begins and comes to an end one rainy morning in a town Mir Ali, in Pakistan's Ancestral Zones close to the Afghan boundary. In Mir Ali's Sher Hakimullah road, Fridays are always considered dangerous. As all people gathered for Friday prayer. The three brothers are deciding to offer their prayer in different mosque.

"The brothers cannot- will not- it is finally decided after some days of deliberation, pray together on Eid”. (Bhutto, 2013, p. 2).

After the careful deliberation, they have decided not to pray together on Eid in one mosque. In accordance with the extract of this narrative or novel settle into a point of view how people reside in cities, countries in offensive tussle or have terrorist also desire to kill them.

"They robbed our fathers of their youth, of their strength. They had no freedom to make their own rules".

(Bhutto, 2013, p. 197).

Inayat is the father of Aman Erum, Sikander and Hayat. He is telling the stories of his forefathers how they have suffered. They had no rights and freedom. The eldest of three brothers Aman Erum, has turned-back to his indigenous land. Sikandar, the second brother is a doctor who missed a son to Taliban's brutality and severe cruelty, has decided to live in his war-stricken area, embracing the never-ending dispute while seeing his wife, Mina, surrendering to insanity.

The whole generation of Mir Ali has sacrificed their lives in this battle. It has taken away the lives of many people. All the residents have paid high price for their life. The eldest brother Aman Erum, who always desired of running away from Mir Ali, He has paid a high price for the consent to study in America and has still had to return home. The second brother Sikandar is a doctor whose depress and psychotic wife, Mina, consistently appears at local funerals as she laments her own son Zalan. She goes to people's home to console them.

"She entered people's homes with a serenity that came with the feeling that she was closer to Zalan. Closer to finding him, to knowing what became and what would now become of her son”. (Bhutto, 2013, 
p. 114).

Mina's husband Sikandar also recalls the memories of his son Zalan, and his heart fills with grief. The child was attached to his father. It's a human nature; parents can't bear the grief of their children.

“Sikandar's heart sinks with the memory of his son's inheritance”. (Bhutto, 2013, p. 171).

The third brother Hayat, devoted to protect and stands up for the town, the place of residence he loves. He was revolutionary and fighting a battle for justice. As a young fellow enrolling to battle for his town he had been conveyed by the impermeable hopefulness of progressives. This was a fight for equity. Hayat has become progressively connected with a radical campaign protesting and objecting the government along with a young fearless lady named Samarra, she was once engaged with Aman Erum but severely betrayed.

"Samarra did not understand what had happened to the boy who used to wait for her by the screen door”. (Bhutto, 2013, p. 176).

As the three brothers each struggles with their burdens to achieve success, the daring young women Mina and Samarra act more straightforwardly in their quest for justice, freedom and serenity.

Bhutto's political fiction is filled with the character's miseries and psychological sufferings because of the war in their region. Mir Ali is located among Pakistan and Afghanistan and it is not suitable for the residents. The inhabitants are living through poor and complex state of prosperity, education and guidance. Not only they are living without the basic facilities of life, the future and destiny of the young generation are also at danger. The 'war on terror' has snatched the rights of youth, laughing, love, bliss, and life and made their lives sad. Fatima Bhutto predicts the lives of the residents of Mir Ali:

"Funerals and burials and prayer evenings became the meeting ground for the resistance". (Bhutto, 2013, p. 50).

Mir Ali's residents were not allowed by government to assemble in groups in any open space, yet the funerals and evening prayers turned into the gathering point for the resistance. Indeed, even the dead were enrolled in the fight toward the state.

In Bhutto's novel 'The Shadow of Crescent Moon' the condition of Mir Ali's hospital was not satisfactory. The unending war on terror has grabbed everything from its residents. They have no right to medicine. The writer depicts the quality of the 'only' hospital in that area. The medical supplies didn't arrive properly in hospital. The medical supply in Mir Ali's hospital is difficult task. It's like snatching the basic right of health from Mir Ali's people. Although, the condition and quality of medicine shipped from Baluchistan is horrible.

"There are pills taken out of their boxes and sold in strips with the expiry date”. (Bhutto, 2013, p. 48).

The pills are removed from their cases and sold with the expiry date. In spite of the way that these medical supplies are expired and should be discarded, the people have their trusts on these expired and bad conditioned medications. They think that these medicines are expired few days ago, and these medicines are usable for them. Due to the scarcity of medical facilities, the lives of the people depend upon these expired medicines. This scarcity of medical facilities is irrefutably influencing the health of people which subsequently impacts the mental health.

"Mosul was a command centre but the Ummah Movement's work here was done”. (Bhutto, 2018, p. 167).

Bhutto's novel 'The Runaways' presents the story of different characters from completely different environment. They are desperate and searching for their lost identity. They join the terrorist's movements. Bhutto considers them an expansive story reaching out over the globe as they produce their various routes from different cities to finally join at a jihad training camp on the edges of Mosul. Monty, Sunny and Oz are from different places, they left their families to come to Mosul. Bhutto investigates the trans-nationality of Islamist enthusiasm. The novel is about radicalization and the acts of fear, but about young generation, their experiences of disruption, and the tensions of having a place that carry them to the crisis. In the novel 'The Runaways' Sunny tries to find a refuge.

"Sunny went for long walks, circling Portmouth, trying to find refuge in what appeared to him to be only a wasteland, a town of forgotten people". (Bhutto, 2018, p. 51).

Sunny is the British born character. He is disappointed by his life. He wanted to escape from his life, and searches for his lost identity. He left his country on the name of Jihad. Bhutto's novel 'The Runaways' is about searching for reality and knowing the truths. It is about Sunny's sexual urges, Monty's compassion, and Anita's aspirations lurk in the shadows, even when the three take their most hazardous choices. 
"This is the struggle our men are destined to face and fight until we win. Our horizons go further than Iraq." (Bhutto, 2018, p. 236).

Bhutto's novel is about the understanding the principle causes that drive young people into joining terrorist activities. In this novel, all the desperate young people are living with complex issues of life. They are trying to search their value and identity in this world. They wanted to find their place to fulfill their dreams. Bhutto tries to give answer by portraying her characters in complex financial, political and personal problems. Due to these complexities, the young generation moves toward radical activities. These radical activities lead them towards terrorism.

Injustice influences people just as societies and the entire world. It is a disease made by human to dehumanize human. Sensation of injustice ruins the peaceful existence of everyone. All the characters in the novel suffered a lot. In part two 'And We Born Again' of the Bhutto's novels 'The Runaways', Monty is in trouble and unfit to battle as he was exhausted form training and exercises.

"He was not suited for this, not for any of it. Not the shooting, not the starving, not any of the drills". (Bhutto, 2018, p. 167).

For Anita Rose, it's the indignity of subjugation and the constraints of desperation and poverty that drive her to search for an elective life. Anita's mom works for rich families. She is 'Maalish Wali' (A massager). She gives massage to wealthy ladies with their expensive scented oils.

\section{Justifications of the Research Questions}

The interpretation of the findings has been justified in the predicted answers of the research questions.

\subsection{What kind of political dilemmas and complexities did Fatima Bhutto discuss in her novel 'The Shadow of the Crescent Moon' and 'The Runaways'?}

The present work highlights the function of politics at social, national, religious, military and communal level to evaluate the effects of politics on our lives and on society which confused and mistrusted the people completely. Dhawan (2015) applauds the efforts made by Bhutto and states that 'The Shadow of the Crescent Moon' is not only the story of Pakistan but it can be apply in any setting of the world because it presents a different of perspective idea because it presents new kind of ideas of the places facing violence and conflicts. Bhutto has rightly done that: the world a new perspective and a voice to address and portray the lives of the war/violence effected people. As indicated by Heywood (1997) politics is portrayed in such different manners: as it is the act of power, exercise of force, the generating collective decisions, the strategy and utilization of untrustworthy strategies, the division of limited assets, economic consumption, and manipulation and likewise. The novel 'The Shadow of the Crescent Moon' has different types of political dilemmas and complexities. This study identifies the deep rooted causes of conflict in North Waziristan. Disputes, differences and discords are caused by culture, race, language, ideologies and religion of a particular society. These factors are inter-related and they give information about the distinctions of individuals in every way that causes contentions, discussions and controversy either globally or locally. We will talk about the dynamics of conflict and crisis situations, which the people of North Waziristan, tribal areas are still facing. It seems that we are living in a fragile land and our world is involved in serious conflicting activities and troubles.

'The Shadow of the Crescent Moon' is a political novel; however, to analyze it from the one point of view might be to miss the humanity within the novel. Bhutto's novel effectively demonstrates the breakdown in basic humanity brought about by unjustness, oppression, mistrust and uncertainty resulting from very dangerous cycles of violence from completely different quarters. Sectarian conflict which has immersed the entire nation in general and the tribal district of Waziristan in particular, has brought about dread psychosis. Bombings in mosques during Eid prayers has damaged and haunted inhabitants that the three young brothers decide to offer Friday prayers at different places for the fear of getting destroyed. Another place in the novel, Sikander, nearly loses his life when interrogated concerning his sect by a Talib and it is Mina's passionate impulse that saves him.

Bhutto belongs to the most persuasive yet violated political families of Pakistan. Her grandfather, Zulfikar Ali Bhutto, Father Murtaza Bhutto and Aunt, Benazir Bhutto lost their lives to the political interests and ruses. Her family tragedy has bearing on her writings about Pakistan and its people. In the novel Bhutto has endeavored to demonize Pakistan's intelligence forces and military presented by Colonel Tariq. In any case, such straight judgment appears to debilitate the ethical force of the novel. Asghar (2000) states about the women that they make the universe of their own by forestalling herself to participate in any exercises of school life, study room and debating society and are denied of opportunity to involve, just to remain and pass on inside their homes. Bhutto has made a sketch of her ladies to be autonomous, brave and non-compliant, different from other postcolonial female characters. Bhutto has depicted extremely good fe- 
male characters with all the more energetic spirits who dominate the three male heroes in the novel and towards the end of the novel reader feels more associated with crying Mina and insubordinate and revolutionary Samarra than any of the three siblings.

\subsection{How has the violence been discussed in the novel 'The shadow of the crescent Moon' and 'The Ru- naways'?}

Violence is quite possibly the most dangerous issues society faces today. It has been expanding for a long time, in the roads of tribal areas. The most widely recognized portrayal of what brutality truly is can be given as antagonism towards a person or thing either through physical or verbal activities, which regularly makes the casualty endure torment. The various sorts of savagery that exist in our multi-social society are out-numbered; however the most apparent ones are sexual and racial brutality. While brutality can be decreased, it won't ever be eliminated because of the nature of people. In this novel, Bhutto presents the characters three brothers and one woman from tribal area the town of Waziristan as representative of cultural hegemony and the life and stories of the novel explore the unpleasant relationship between Pakistan and America on 'war on terror'. The young generation of tribal belt of Waziristan suffered and they pushed into a battle they never know, as they have lost their destination, direction and identity. Hussain (2002) contends that Pakistan was fronting a predicament how to harmonize its national affairs with the goals of worldwide circumstance. Rashid (2009) states that because of the reality 9/11, the conflict in Afghanistan, and the attack of Iraq; the west has been fighting a "war on terror" through strength and by means of the foundation of social orders in the area.

The novel 'The Shadow of the Crescent Moon' is loaded up with political imbroglios and has been written in the excellent and most artful way. In this novel, the investigation of the information demonstrates that every one of the principle characters face perplexing and complex circumstances which become the reason for ruin. Through the investigation of this novel the researchers have endeavored to depict that the use of political issues in a negative manner in the society can cause disruptiveness, annihilation and intensification in the masses and positive utilization of politics can bring a condition of public serenity and financial prosperity. Aman, Sikandar, Hayat, Mina and Samarra the principle characters of the novel have made individual sacrifices to accomplish opportunity, freedom and power for their friends and family just as for individuals of Mir Ali their ancestral home town. Aman Erum needed to go out anywhere. He wanted to be free, and to travel without any restriction. The others young men of his age didn't appear to feel limited by the nation's wild boundaries; they didn't feel confined the manner in which he did. Aman Erum needed to travel to another country to improve for his family, his old neighborhood and for his own better future regardless of the convoluted and upset states of the Mir Ali.

It is a tragic story of the lives of three brothers and two women and a perspective on how and in what manner or way people live in particular countries in war or have terrorists also feel need to kill them. The eldest brother Aman Erum who always wanted to escape from Mir Ali, and has returned home from America has paid a high price for permission to study in America. The second brother Sikandar is a doctor whose wife Mina goes to attend local funerals as she has already lost her son, it seems as she mourns her own son. Each character in the novel struggles with their burdens in an attempt to find justice. No one could express what they thought, freedom of action, movements, and speech all are identified as dangerous for residents of Mir Ali, and death is the punishment for violating the rules. Lack of freedom and the constant threat of insecurity effect the psychological and emotional health of everyone. They are helpless and desperate to realize the importance of their own life, the worth of the life of Mir Ali's people. War is the reason for injustice, desperation, and deprivation of proper health facilities for the citizens of Mir Ali residing there for years without any right of safety, security and significance for their existence. Every day thousands are killed brutally and treated inhumanly.

\subsection{How does political divisiveness take on human relationships?}

Political unfairness includes the infringement of individual freedoms, including the refusal of fair treatment, violations on rights to speak freely, and insufficient security from barbarous punishment. Such inequality frequently comes from biased strategies, and includes political frameworks. Political imbroglios is a convoluted situation made because of political disharmony among the political bodies in law settling on and political choices bringing about a chaos that further strengthens the contentions. Leftwich (1984) states that politics stays alive at each level, conditions and in each domain of human social orders. Politics is the governing characteristic of all cultural and social groups. Politics exists not just inside the specific domain of the state, yet it involves in a private domain of life. Thus, all individuals are in some way engaged with politics. It impacts the lives of us all whether or not we partake in politics. Politics is at the core of all collective social activity, public and private, formal and informal in all numerous human organizations, human groups and social orders.

Political practice and manners in Pakistan has developed different and separate problems in the organizational work- 
ing of the political parties as well as of the democracy. Along with the agreements there are also disagreements between different countries and this is politics between nations instead of politics within nations. The genuine problem is that the old fraudulent established and very affluent ruling class does not wish to disqualify or hand over their superior position, authority and special privileges by allowing all citizens to share in governance. All the people who are in social power and have the ability to control people or things always create anxieties and uncertainty to insecure the nation and misdirect them so that individuals cannot know their politics. The research in the field of politics and its impacts will be increased to great extent. It is quite perplexing to see the disastrous effects of the catastrophic incident of 9/11 'war on terror' an unending war on neighboring Pakistan and its people as it has exploited the youth of the tribal areas. This research aims to highlight variety of problems and issues that confront the societies. There is no country in the world that does not face various problems, especially social issues and Pakistan and its neighboring countries are not different.

'The Shadow of the Crescent Moon', debut novel by Fatima Bhutto, is a political novel with profound humanitarian issues. It is set in Mir Ali; a war troubled town of Pakistan's FATA of North Waziristan. The novel unfolds over one morning and revolves around three totally different brothers and two women. After breakfast the brothers go their separate ways. The eldest brother Aman Erum hires taxi to a local masjid. The second, Sikander, a doctor heads off to work at hospital and therefore the youngest, Hayat, rides out of the city on his bike. The novel is structured around hours during a single, eventful day, with numerous back stories filled through flash backs pushing the reader in multiple directions. The eldest of the three brothers Aman Erum had, like several young Pakistanis, nurtured a dream to complete his study in America and he with success secures a desired place in an American university to study business, however needs to sell his soul to commissioned military officer Colonel Tarik to get the requisite papers. He is one of several Pakistani young men who plan to travel abroad for higher studies however have to face hardships in procuring necessary documents and have to compromise on numerous things together with their convictions and beliefs. Sikander is a doctor by profession. The war ruins the peace of his family. Hayat, the younger brother becomes a revolutionary to fight injustice and oppression. Samarra's life is victim of assorted conflicts round her and swept up by politics and rebellion. Mina, the wife of Sikander additionally plays a major role within the novel. She is symbolic of the Pakistani ladies who have endured worst because of terrorism. She has lost her son in an explosion and also the agony and trauma she goes through is unspeakable. Veenhoven (2014) states about freedom the chance to pick a norm, peaceful personal satisfaction with no restrictions.

The current examination has also featured the political complexities not just in Pakistani society and in Muslim families who moved in foreign nations however it talks about politics at various levels like individual, social, common and military political level. This investigation uncovers politics at individual level by affirming that how individuals play, cheat and endeavor their relations for the sake of adoration and love, the delightful way they do politics with others just to acquire individual benefits and advantages. This investigation additionally portrayed the force of military that it has the option to assume control over the state, at whatever point it needs to do as such. This examination has highlighted the different prevailing systems that overwhelm our lives as well as our entire society.

\subsection{How social radicalization is discussed in Bhutto's novels 'The Shadow of the Crescent Moon' and 'The Runaways'?}

Naqi (2008) contends that 'Radicalization' would create extremism in the statement of the nobility and conclusiveness of one's convictions and their supremacy. Radicalism is the prevalence or adoption of an unreasonable situation in any trouble. Terrorism usefulness coercively inconvenience of thoughts, plans or views, etc. on the unwilling. This specific exploration was intended to improve insight and sound perception of social radicalization and expand what has been recently thought about this theory. Radicalization is the way toward embracing extremist ideologies and convictions and participating in illegal violent extremist activities and terrorism. Ideology and action both are at times connected or inter linked, however not always. We need to comprehend the distinctions between them due to the undeniable fact that many individuals who have extremist reasoning, thoughts and violent justifications cannot be considered terrorists. Moreover, even a large number of the individuals who hold a militant jihad banner are not profoundly religious and have just a short view and comprehension of the extreme religious ideology they claim to address. However, if we comprehend radicalization into violent extremism, we need to have more understanding and awareness of a doctrine or a religion.

Generally there are various processes for various individuals to participating in various radical terrorist activities at various points in various social contexts. Neumann (2010) is of the view that "Extremism goes against a society's beliefs, values, principles and basic human rights and it prompts political ideologies”. It can likewise be used to portray the hidden techniques through which political groups tries to achieve their objectives and desires, by adopting specific thoughts or strategies that reveal negligence and disregard the life, opportunity and human rights of others. It can goes 
against the principles of all human rights. Dolnik (2009) states that "the firefighter way to deal with reviewing the subject and western bias is likewise creating limits in exploring how and why people arise as radicals and terrorists".

Radicalization, belongingness and alienation-these are the important subjects of Bhutto's famous novel, 'The Runaways'. The novel depicts the existences of three youngsters-Anita, Monty and Sunny-who escape their lives in Pakistan and run away to Iraq during the rising of the Islamic State. Bhutto is the writer of a book on poetry; two works of non-fiction, including her memoir 'Songs of Blood and Sword', and now, two works of fiction. In a meeting with 'The Wire', she discusses why she was drawn towards the lives of radicalized youngsters, and why she accepts they "should be treated with sympathy before they commit these horrible errors."

The novel 'The Shadow of the Crescent Moon' has been written in a context of the 'war on terror'. It is an account of three young brothers and two young ladies. In the novel there are three brothers, who adopt various lifestyles after the death of their father, and the two young female characters Samara and Mina. In this novel, ladies are the strength and extraordinary spirit of the story. The novel is set in the tribal area of northwest Pakistan and involves three brothers who are getting ready to celebrate Eid, the Muslim feast toward the end of Ramadan. Aman Erum, the oldest son, has decided to leave his darling and establish a business away from his ancestral town. The middle brother has become a doctor and the most energetic and youngest brother has joined his brother's darling as an insurgent. In the novel, Mir Ali is the point of convergence for the armed struggle between the army of Pakistan and local residents who desire their own freedom. One gets the feeling of a long-running, life-and-death struggle in the northwest of Pakistan. Obviously the writer's sentiments are with the insurgents. There is an insurgent plot to murder a minister, and the story is by all accounts seems to be headed to a climax there, yet the novel finishes in uncertainty. There is some uncertainty concerning who the insurgents are; some are Taliban; some are common people.

Bhutto's 'The Runaways' attempts to show, with extraordinary empathy and sincerity, how young people from Pakistan and Britain cross the boundaries of their peaceful house towards the battlefield. They are from London and Karachi and travelling towards Iraq. In this simple structured novel, there are three principle characters that discover their path to Nineveh. Sunny belongs to Pakistan. Anita/Layla is a helpless Christian young girl. She is from Karachi and Monty is from Karachi. He is the child of rich man. Monty loves Layla.

\section{Conclusion}

Bhutto's novels 'The Shadow of the Crescent Moon' and 'The Runaways' are an attempt to highlight the political imbroglios and social radicalization and its impact on youth. The current study evaluated and discussed the political imbroglios at various levels such as social, communal, national and religious level. The detail investigation of the selected narrative shows that political convolutions in the state cause chaotic environment, disintegration, physical and psychological disorders and ruin lives and careers of the people. The entire context of the narrative 'The Shadow of the Crescent Moon' written by Bhutto present the atmosphere of war, bloodshed, cries and tears wrapped with the burning smoke of Mir Ali, a tribal area. The overall views conclude that every effort for secure and better future in the tribal areas would be fruitless without considering the problems of youth regarding the productive resources and cultural identity living in the tribal areas. This leads to us making strong decisions of religion, culture and freedom for the residents of such troubled areas. By depicting the social and political connections, she brings into our mind the perception of the war on terror, and to the individuals who are its most exceedingly worst victims. The psychological understanding of 'war on terror' depict that neither West nor the country's political mindset has endured those critical issues that the young people of the tribal areas face. As a result of this ceaseless conflict, their destiny is fixed as 'lost generation'.

\section{References}

Abulof, U. (2017). Introduction: Why We Need Maslow in the Twenty-First Century. Society, 54(6): 508.

Alavi, M. and Carlson, P. (1992). A Review of MIS Research and Disciplinary Development. J. Mngt Inf. Syst., 8(4), 45-62.

Artemov, A. and Kleimenov, M. (2010). Concept and types of criminal extremism. Herald of Omsk University, 3(24), 237.

Ary, D. (1996). Introduction to research in education. $5^{\text {th }}$ edition. Toronto: Harcourt Bruce College Publications.

Asghar, A. A. (2000). The Emergence Feminism among Indian Muslim Women. Oxford: Karachi.

Burns and Grove. (1997). The Practice of Nursing Research: Conduct, Critique, and Utilization. $3^{\text {rd }}$ ed. WB Saunders Company, Philadelphia.

Dhawan, B. (2015). “Cultural Hegemony in the Shadow of the Crescent Moon”. 9-26. Print.

Dolnik, A. (2009). Lecture, in-house PIPS session on radicalization. Islamabad: A Narratives Publications.

Erikson, E. H. (1959). 'Identity and the Life Cycle: Selected Papers’. Psychological Issues. 
Fair, C. (2007). The Hadassah Challenge: Militancy and Religious Education in Pakistan (Washington, D.C.: United States Institute of Peace Press), p. 2.

Heywood, A. (1997). Politics. Macmillan Press LTD, London.

Hussain, R. (2002). Pakistan's Afghan Policy in 'The Anatomy of a Conflict: Afghanistan and 9/11'. New Delhi: Roli Books Pvt. Ltd.

Jackson, R. (2005). Security, Democracy, and the Rhetoric of Counter-Terrorism. Democracy and Security, 1(2), pp. 147-171.

Jadoon, A. Wasif, S., and Imtiaz, U. (2018). Literary Responses to the War on Terror: A Psychological Analysis. G.S.S.R., Vol. III, No. IV.

Khan, R. M. (2012). Afghanistan and Pakistan: Conflict, Extremism, and Resistance to Modernity. Karachi: Oxford University Press.

Leedy, P. and Ormrod, J. (2001). “Practical research: Planning and design. (7th Ed.). Upper Saddle River, NJ: Merrill Prentice Hall. Thousand Oaks: SAGE Publications.

Leftwich, A. (1984). What is Politics? The activity and its study. Basil Blackwell, Oxford.

Lepeshkov, Y. (2010). The definition of terrorism and the universal international standards in the fight against them. Journal of International Law and International Relations, 4. http://evolutio.info/content/view/1754/232/.

Marshall, C. and Rossman, G. B. (1999). Designing qualitative research. (3rd Ed.). Thousand Oaks, CA: Sage Publications.

Miller, J. D. B. (1962). The nature of politics. Gerald Duckworth \& Co. Ltd, London.

Mills, J. (2014). Methodology and methods. In Jane Mills \& Melanie Birks (Eds.), Qualitative methodology: A practical guide (pp. 31-47). Thousand Oaks, CA: Sage.

Modebadze, V. (2010). The term politics reconsidered in the light of recent theoretical developments. IBSU Scientific Journal (IBSUSJ). International Black Sea University, Tbilisi, Vol.4, Iss.1, pp. 39-44.

Mujcic, R. and Oswald, A. (2016). Evolution of well-being and happiness after increases in the consumption of fruit and vegetables. Am J Public Health, 106(8): 1504-10.

Naqi, H. (2008). Role of Media in Radicalization. Lahore: Pak Institute for Peace studies.

Neuman, P. (2010). "Prisons and Terrorism Radicalization and De-radicalization in 15 Countries”, A Policy report published by the International Centre for the Study of Radicalization and Political Violence (ICSR).

Ohrnberger, J., Fichera, E., and Sutton, M. (2017). The relationship between physical and mental health: A mediation analysis. Social Science \& Medicn, Vol. 195, pp. 42-49.

Patton, M. (1990). Qualitative evaluation and research methods (2nd ed). Newbury Park, CA: Sage.

Pavan, G. K. (2014). Review Article on Research Methodology. International Journal of Innovative Research and Development, Vol. 3 , Issue 7.

Polit, D. F. and Hungler, B. P. (1991). Nursing research principles and methods. 4th ed. Philadelphia: JB Lippincott.

Rais, R. B. (2009). Lecture, in-house PIPS session on radicalization. Islamabad: A Narrative Publications.

Ramakrishna, K. (2010). From Virtual to Violent: Preliminary Conceptual Exploration of Religious Radicalization in Youth. Malaysia: Ministry of Foreign Affairs.

Rashid, A. (2009). Descent into Chaos. London: Penguin Books.

Roy, O. (1994). The Failure of Political Islam. London: I.B. Taurus.

Saldana, J. (2015). The coding manual for qualitative researchers. Thousand Oaks, CA: Sage.

Sethna, R. (2014). Review: The Shadow of the Crescent Moon by Fatima Bhutto. The Dawn. Retrieved on $25^{\text {th }}$ Sep, 2020.

Sheikh, F. (2009). Making Sense of Pakistan. New York: Columbia University Press.

Sial, S. and Anjum, T. (2010). Jihad, Extremism and Radicalization: A Public Perspective. Retrieved from www.pakpips.com.

Suganami, H. (2003). Reflections on 11 September. In 11 September 2001: War, Terror and Judgement. Pp. 3-12. Taylor \& Francis Group, London.

Tanner. (2003). Reading and critiquing research. Br J Perioper Nurs., 13(4).

Thakur, R. (2012). A Changing Chessboard: The New Great Game in Afghanistan Global Asia. A Journal of the East Asia Foundation, Seoul www.globalasia.org.

Veenhoven, R. (2014). Freedom and Quality of Life. In: Michalos A. C. (eds.), Encyclopedia of Quality of Life and Well-Being Research. Springer, Dordrecht.

Yin, R. K. (2002). Case Study Research, Design and Methods. 3rd ed. Newbury Park, Sage Publications. 